leader of the Danish Siam expedition. He was on the staff of the Department of Zoology at Copenhagen from 1902 until 1933, and during this period he travelled with expeditions to the West Indies (1905-6), the Pacific (1914-16) and the Indo-Malayan region (1922 and 1929-30), and collaborated with the Danish Ingolf, the German Plankton, the German and Swedish South Polar and the American Albatross Expeditions. From 1927 until a fow months before his death he was occupied chiefly with the "Monograph of the Echinoidea" published at the expense of the Carlsberg Fund. This fund also subsidized his research, so that from 1933 onwards he was freed from all other commitments.

When Mortensen started work on the Echinoidea in 1897, the old era was closing with the life of its greatest figure, Alexander Agassiz. The classification of the fossil and Recent forms was alike based on the coronal and apical plates, and no fundamental advance seemed possible. Yet already by 1907 the work of the Ingolf expedition had enabled Mortensen to revolutionize the taxonomy of the Cidaridæ, developing Doederlein's pioneer attempt to use the pedicellariæ in classification. Further expeditions provided quantities of new material and made possible the application of his methods to other groups of Regularia; and though at first his ideas met with authoritative and obstinate opposition, he lived to see them established in the end.

Mortensen's new taxonomic methods broadened the basis of classification by adducing, in addition to the characters formerly used, the micro-structure of the radioles, the form of the pedicellariæ, the distribution of spicules in the soft parts and the development of the pluteus larva-all of them features easily lost in fossilization-so that the placing of fossil species within his scheme became impossible in, for example, the Cidaridæ and Camarodonta. On the other hand, in groups with few living but many fossil representatives, an understanding of the palæontological background was essential. He accordingly sought the guidance of Prof. H. L. Hawkins in studying fossil Echinoidea, and this helped to give balance to his views of phylogeny and descent.

His opportunities were unique, for in the vigour of his youth he worked with the rich new harvests of the expeditions, and in the ripeness of his experience he could devote himself entirely to completing his life's work. He was ideally fitted to make the most of these chances, for his immense capacity for work was guided by a harmonizing intelligence of extraordinary power. His work as a draughtsman and preparator was unsurpassed. His English style was lucid and forceful, marked, but not disfigured, by a quaintness of expression inevitable in the use of a language not native to the writer. There is never any blurring in his work of the limit between observation and inference, and in his "Monograph of the Echinoidea" he was as much concerned to define what is still to be done as to summarize what is already known.

Although he outlived most of his contemporaries in the field, his mind was continually refreshed by contacts with younger workers, whom he fired with his own enthusiasm. His fellow-workers are thankful that his knowledge did not pass unrecorded and grateful to those whose trust in him was so amply repaid.

I acknowledge the help of Prof. Christian Poulsen with biographical details.

\section{Prof. J. J. Nolan}

JoHN J. NolaN was born in Omagh, County Tyrone, on December 28, 1888. Entering University College, Dublin, in 1906, he graduated in 1909 with the highest distinction in experimental physics and was immediately appointed to the staff of the Physics Department.

The influence of J.A. McClelland, in collaboration with whom he published in 1911 his first researchan investigation of the electric charge on rain-established Nolan's lifelong interest in atmospheric electricity. Later followed a series of papers on the mobility of ions produced in air by spraying water and by radioactive radiations in air under various conditions of drying. His most important work concerned the equilibrium of ionization in the lower atmosphere. Extensive observations, over many years, of the nucleus content and the number of large and small ions enabled various assumptions concerning the equilibrium to be tested, and showed finally that true equilibrium rarely exists. Other researches concerned the mass and size of condensation nuclei, derived from measurements of their diffusion coefficient and rate of fall under gravity, using a method which he had himself developed. His last paper (in conjunction with P. Burke) established a connexion between the radium $A$ content of the atmosphere and the number of nuclei. The results of his investigations, embodied in about forty papers, many the result of collaboration with his brother, P. J. Nolan, and his research students, constitute a lasting record of the work of the school of atmospheric electricity which he developed.

On MoClelland's early death in 1920, Nolan succeeded him as professor of experimental physics. He was an inspiring teacher with a fine voice and a commanding presence which enabled him to capture and hold the interest of very large first-year classes. Every lecture was a model of clarity, force and accuracy, emphasizing the physical ideas and using relatively little mathematics. For many years he was a member of the governing body of the College and of the Senate of the National University. In 1940, when A. W. Conway became president of the College, Nolan succeeded him as registrar, and the administrative responsibilities of this post gradually curtailed his opportunities for research.

A member of the Royal Irish Academy from 1920, he became secretary in 1923, a position which he retained until his election as president in 1949; thus for almost thirty years he served the Academy. He guided its fortunes during the formative years of the young Irish State and ensured that it retained in the learned life of the new Ireland the position to which its long and distinguished tradition entitled it. Nolan's work on atmospheric electricity had given him an interest in other aspects of geophysics, and it was largely the advice he had given to successive Irish Governments which led Mr. de Valera, as head of the Government, to establish in 1947 a School of Cosmic Physics in the Dublin Institute for Advanced Studies. Nolan became the first chairman of the governing board of the new School.

A silent and reserved man, Nolan nevertheless possessed a devastating wit which he exercised in congenial company. Always courteous and eventempered, he rarely offered advice; but when he did, his balanced judgment and shrewd Ulster common sense invariably produced advice which it was unwise to disregard. A man of wide culture, in 
his early years he wrote some excellent light satirical and scientific verse. He married in 1914 Miss Teresa Hurley and had four sons, the loss of one of whom, killed in 1945 while serving in the Royal Navy, he felt very deeply. During the past few years his health deteriorated, though he continued his many activities to the end of 1951. Attempting to resume work after Easter, he collapsed and died on April 18 while lecturing on electromagnetic induction to a large class.

His death leaves a gap in the life of his College and in the scientific life of Ireland which will remain unfilled for a long time. Thomas E. Nevin

\section{Mr. Charles McDermid}

Charles McDermid, who was born in Darlington in 1868 and died at Bexhill-on-Sea on May 7, was associated with the mining and metallurgical industries for more than fifty years. In his early years he was secretary to the late Sir David Dale, who was chairman of the North Eastern Railway Company and of a number of coal, iron and steel companies. Later he went to London as assistant secretary of the Iron and Steel Institute and in 1900 was appointed secretary of the Institution of Mining and Metallurgy. $\mathrm{He}$ was largely responsible for the growth both in numbers and prestige of that Institution.

In 1903 a representative meeting was held at the Mansion House to inaugurate a proposal for a memorial to the late Sir Henry Bessemer. Mr. McDermid became honorary secretary to that committee, and it was largely due to his personal efforts that funds were provided to build the Bessemer Laboratory at the Royal School of Mines. A strong liaison has always existed between the Institution of Mining and Metallurgy and the Royal School of Mines, and for many years Mr. McDermid represented the Institution on the governing body of the Imperial College, in the founding of which he had also taken an active part.
In 1920 he was invited to become secretary of the Institution of Mining Engineers, the previous headquarters of which had been in Newcastle upon Tyne, and he continued to hold these two secretaryships until he retired in June 1939. On the outbreak of war, however, he returned to the Institution of Mining Engineers and guided it through the difficult war years.

One of his greatest achievements was the major part he played in the organization of the Empire Mining Congress, the object of which was to bring together, triennially, representative mining engineers, metallurgists and economic geologists to discuss. problems common to their relative Dominions and Colonies. The first Congress, held in London in 1924, was followed by meetings in Canada, South Africa. and London again. He strongly urged the view that the British Empire and the United States should collaborate as closely as possible to preserve the peace of the world, and to compile a complete record of the mineral resources of these two nations for use in the event of a further conflict.

Charles McDermid travelled widely, and wherever he went he made and retained friends. His honesty of purpose, his kindness of heart and his interest in young engineers endeared him to all who came into. contact with him. His death will be a sad blow to a. host of friends throughout the world, both in distant cities and in the lonely outposts where mining men carry out their professional duties.

$$
\text { J. A. S. RrTson }
$$

WE regret to announce the following deaths :

Prof. John Dewey, emeritus professor of philosophy in Columbia University, New York, on June 1, aged ninety-two.

Sir James Irvine, K.B.E., F.R.S., principal and vice-chancellor of the University of St. Andrews, on June 12, aged seventy-five.

\section{NEWS and VIEWS}

\section{Linnean Gold Medal: Mr. I. H. Burkill}

THE presentation of the Linnean Gold Medal for 1952 to Mr. I. H. Burkill, at the anniversary meeting of the Linnean Society of London on May 24, was an overdue recognition of the valuable work accomplished in a long life by this still active botanist. Since 1900 he has been connected with the botany and botanical products of tropical Asia; during 1912-25 he was director of the Botanic Gardens, Singapore, in which post he succeeded Mr. H. N. Ridley. After his retirement he continued his botanical studies and (in part with the late Sir David Prain) specialized, though by no means exclusively, on the genus Dioscorea. During 1937-44 he was botanical secretary to the Linnean Society.

Burkill's published work is not only considerable in quantity and varied in subject-matter but also of a high quality. His "Dictionary of the Economic Products of the Malay Peninsula" (Crown Agents for the Colonies, 2 vols., pp. $2402 ; 1935)$ is one of the most useful books of reference not only to the economic plants and other products of the Malay Peninsula but also to tropical economic botany in general. Many of the articles, arranged alphabetically according to subject, make excellent reading. Space will allow no more than a mention of Burkill's monographic researches on Dioscorea. These are being continued. In Singapore, he was interested in problems of insect pollination, on which he published a series of papers. His work on the yams led him to an investigation of the structure and life-history of the black bryony and several important accounts of this plant were the result. Many of Burkill's papers naturally dealt with plants of tropical Asia and were published in various journals in Britain and other countries. The many botanists who have received help from $\mathrm{I}$. H. Burkill are gratified that he has been awarded the highest honour of the Linnean Society, and all his friends wish him health and strength to continue his researches on plants of the tropical and temperate regions.

\section{National Research Council of Canada: \\ Dr. C. J. Mackenzie, C.M.G., F.R.S.}

DR. C. J. MACKENZIE has resigned from the presidency of the National Research Council of Canada to become chairman of Atomic Energy of Canada, Ltd., and is succeeded by Dr. E. W. R. Steacie (see p. 1049). Dr. Mackenzie is a graduate in engineering of Dalhousie and Harvard Universities, and as a 